\title{
Microstructure and Hardness of Scandium Trialuminide with Ternary Rare-Earth Additions
}

\author{
Yoshihisa Harada ${ }^{1, a}$ and David C. Dunand ${ }^{2, b}$ \\ ${ }^{1}$ Advanced Manufacturing Research Institute, National Institute of Advanced Industrial Science and \\ Technology (AIST), 1-2-1 Namiki, Tsukuba, Ibaraki 305-8564, Japan \\ ${ }^{2}$ Department of Materials Science and Engineering, Northwestern University, 2220 Campus \\ Drive, Evanston, IL 60208-3108, USA \\ aharada.y@aist.go.jp, bdunand@northwestern.edu
}

Keywords: Microstructure, Micro-hardness, Lattice parameter, $\mathrm{Al}_{3} \mathrm{Sc}$, Scandium, Rare-earth, SEM/EDS, X-ray diffraction.

\begin{abstract}
The microstructure of ternary $\mathrm{Al}_{3}\left(\mathrm{Sc}_{1-\mathrm{y}} \mathrm{RE}_{\mathrm{y}}\right)$ intermetallic compounds (where $\mathrm{RE}$ is one of the rare-earth elements $\mathrm{La}, \mathrm{Ce}, \mathrm{Nd}, \mathrm{Sm}, \mathrm{Eu}, \mathrm{Yb}$ or $\mathrm{Lu}$ ), was investigated as a function of $\mathrm{RE}$ concentration for $0<\mathrm{y} \leq 0.75$. Alloys with $\mathrm{La}, \mathrm{Ce}, \mathrm{Nd}, \mathrm{Sm}$ or $\mathrm{Eu}$ additions consist of a $\mathrm{L}_{2}$ phase containing a dendritic second phase with $\mathrm{D}_{19}(\mathrm{La}, \mathrm{Ce}, \mathrm{Nd}, \mathrm{Sm})$ or $\mathrm{C} 11_{\mathrm{b}}(\mathrm{Eu})$ structure. Alloys with $\mathrm{Yb}$ or $\mathrm{Lu}$ additions show a single $\mathrm{L1}_{2}$ phase. The $\mathrm{RE}$ solubility limits at $1373 \mathrm{~K}$ in the $\mathrm{L}_{2}-\mathrm{Al}_{3}\left(\mathrm{Sc}_{1-\mathrm{y}} \mathrm{RE}_{\mathrm{y}}\right)$ phase are very low for $\mathrm{La}, \mathrm{Nd}, \mathrm{Ce}$ and $\mathrm{Eu}(0.08-0.41$ at.\% or $\mathrm{y}=0.0032-0.0164)$, low for $\mathrm{Sm}$ (3.22 at.\% or $\mathrm{y}=0.1288$ ) and complete for $\mathrm{Yb}$ and $\mathrm{Lu}$. The lattice parameter of the $\mathrm{L}_{2}$ solid-solution increases linearly with RE concentration and the magnitude of this effect is correlated with the atomic size mismatch between Sc and the RE elements. The Vickers micro-hardness of the $\mathrm{L1}_{2}$ solid-solution increases linearly with increasing RE concentration.
\end{abstract}

\section{Introduction}

Scandium trialuminide, $\mathrm{Al}_{3} \mathrm{Sc}$, is of interest because of its low density $\left(3.03 \mathrm{Mg} \mathrm{m}^{-3}\right.$ ), relatively high melting point $(1593 \mathrm{~K})$ and potentially useful high-temperature strength. $\mathrm{Al}_{3} \mathrm{Sc}$ has the cubic $\mathrm{L}_{2}$ structure which is expected to show enhanced ductility, because of the high crystallographic symmetry and thus, the high number of possible slip systems. Despite its $\mathrm{L}_{2}$ structure, polycrystalline $\mathrm{Al}_{3} \mathrm{Sc}$ is brittle at room temperature [1]. Partial substitution of Sc by other elements may increase the ductility of $\mathrm{Al}_{3} \mathrm{Sc}$ and also decrease the cost of the alloy. However, very little is known about the alloying behavior of $\mathrm{Al}_{3} \mathrm{Sc}$, with the exception of a recent study investigating the solubility limit of the transition metals (TM) Y, Ti, Zr, Hf, V, Nb and Ta [2]. It was found that solid-solution strengthened $\mathrm{Al}_{3}\left(\mathrm{Sc}_{1-\mathrm{y}} \mathrm{TM}_{\mathrm{y}}\right)$ showed improved creep properties as compared to binary $\mathrm{Al}_{3} \mathrm{Sc}$ [3]. The alloying behavior of $\mathrm{Al}_{3} \mathrm{Sc}$ is also important for the rational design of Sc-containing aluminum alloys, in which small volume fractions of coherent $\mathrm{Al}_{3} \mathrm{Sc}$ particles are precipitated [4]. In multi-component alloys, these $\mathrm{Al}_{3} \mathrm{Sc}$ precipitates often contain other alloying elements in solid-solution [5], which can improve the strength and coarsening resistance of the precipitates. One study indeed exists, showing that Gd, Ho and Er added to Al-Sc alloys lead to increase hardness [6]. In the present study, the microstructure and hardness of ternary $\mathrm{Al}_{3}\left(\mathrm{Sc}_{1-\mathrm{y}} \mathrm{RE}_{\mathrm{y}}\right)$, where scandium is replaced substitutionally by seven rare-earth elements ( $\mathrm{La}, \mathrm{Ce}, \mathrm{Nd}, \mathrm{Sm}, \mathrm{Eu}, \mathrm{Yb}, \mathrm{Lu}$ ), is investigated as a function of alloying element concentration for $0<\mathrm{y} \leq 0.75$.

\section{Experimental Procedures}

Button ingots of ternary $\mathrm{Al}_{3}(\mathrm{Sc}, \mathrm{RE})$, where $\mathrm{RE}$ was chosen from the rare-earth elements $\mathrm{La}, \mathrm{Ce}, \mathrm{Nd}$, $\mathrm{Sm}, \mathrm{Eu}, \mathrm{Yb}$ or $\mathrm{Lu}$, were cast by non-consumable electrode arc-melting of the pure elements on a water-cooled copper hearth under a purified argon atmosphere. A total of 21 different ternary compositions were prepared with stoichiometry $\mathrm{Al}_{3}\left(\mathrm{Sc}_{1-\mathrm{y}} \mathrm{RE}_{\mathrm{y}}\right)$ where $\mathrm{y}=0.02,0.04$ and 0.1 for $\mathrm{RE}=\mathrm{Ce}$ 
or $\mathrm{Nd}, \mathrm{y}=0.1,0.25$ and 0.5 for $\mathrm{RE}=\mathrm{La}, \mathrm{Sm}$ or $\mathrm{Eu}$, and $\mathrm{y}=0.25,0.50$ and 0.75 for $\mathrm{RE}=\mathrm{Yb}$ or $\mathrm{Lu}$. The resulting ingots showed a weight loss under $1 \%$ as compared with the initial charge. Finally, the ingots were homogenized in argon for 24 hours at $1373 \mathrm{~K}$ for La, Ce, Nd, Sm, Eu and Lu, or 96 hours at $1123 \mathrm{~K}$ for $\mathrm{Yb}$.

Metallographic preparation consisted of mounting and polishing with $\mathrm{SiC}$ paper and $0.05 \mu \mathrm{m}$ $\mathrm{Al}_{2} \mathrm{O}_{3}$. Energy dispersive X-ray spectroscopy (EDS) and scanning electron microscopy (SEM) were then performed to obtain the compositions of the bulk samples and individual phases. Portions of the homogenized ingots were pulverized and the resulting powders, sieved to less than 250 mesh size (75 $\mu \mathrm{m}$ ), were analyzed by X-ray diffraction (XRD) using $\mathrm{Cu}-\mathrm{K} \alpha$ radiation. Lattice parameters were calculated by the least-squares method using the JADE program (Rigaku, Tokyo). After polishing, the Vickers micro-hardness of the $\mathrm{L}_{2}$ matrix phase was measured using a $200 \mathrm{~g}$ load and an indentation time of $10 \mathrm{sec}$, with the average of 5 measurements reported.

\section{Results and Discussion}

Microstructure. The binary $\mathrm{Al}_{3} \mathrm{Sc}$ was found by $\mathrm{X}$-ray diffraction to have the $\mathrm{L}_{2}$ structure with a lattice parameter $a=4.103(1) \AA$, with previous results [2]. The bulk composition was 74.8 at.\% Al 25.2 at.\% Sc as measured by wet chemical analysis and this value was used to calibrate the EDS detector [2]. The microstructures of homogenized $\mathrm{Al}_{3}\left(\mathrm{Sc}_{1-\mathrm{y}} \mathrm{RE}_{\mathrm{y}}\right)$ alloys for $\mathrm{y}=0.02(\mathrm{Ce}, \mathrm{Nd}), 0.1(\mathrm{La}$, $\mathrm{Sm}, \mathrm{Eu})$ are shown in Figs. 1(a)-(e). These alloys consist of a majority $\mathrm{Ll}_{2} \mathrm{Al}_{3}(\mathrm{Sc}, \mathrm{RE})$ phase and a low volume fraction of a dendritic $\mathrm{Al}_{3}(\mathrm{RE}, \mathrm{Sc})$ phase. The latter phases was found by $\mathrm{EDS}$ to be $\mathrm{D}_{19}-\mathrm{Al}_{3}\left(\mathrm{La}_{0.96} \mathrm{Sc}_{0.04}\right), \quad \mathrm{D} 0_{19}-\mathrm{Al}_{3}\left(\mathrm{Ce}_{0.82} \mathrm{Sc}_{0.18}\right), \quad \mathrm{D} 0_{19}-\mathrm{Al}_{3}\left(\mathrm{Nd}_{0.79} \mathrm{Sc}_{0.21}\right)$ or $\mathrm{D}_{19}-\mathrm{Al}_{3}\left(\mathrm{Sm}_{0.91} \mathrm{Sc}_{0.09}\right)$, respectively,

independent of the overall composition (Table 1). In the case of $\mathrm{Eu}$ addition (Fig. 1(e)), the alloy exhibits a $\mathrm{L}_{2}$ matrix and low volume fractions of an Al-phase and a second phase found to be $\mathrm{C} 11_{\mathrm{b}}-\mathrm{Al}_{4}\left(\mathrm{Eu}_{0.975} \mathrm{Sc}_{0.025}\right)$ due to non-existence of a trialuminide phase in the Al-Eu system. As shown in Figs. 1(f) and (g), $\mathrm{Al}_{3}\left(\mathrm{Sc}_{1-\mathrm{y}} \mathrm{RE}_{\mathrm{y}}\right)$ alloys for $\mathrm{y}=0.25(\mathrm{Yb}, \mathrm{Lu})$ show a single $\mathrm{L1}_{2}$ phase with some Kirkendall

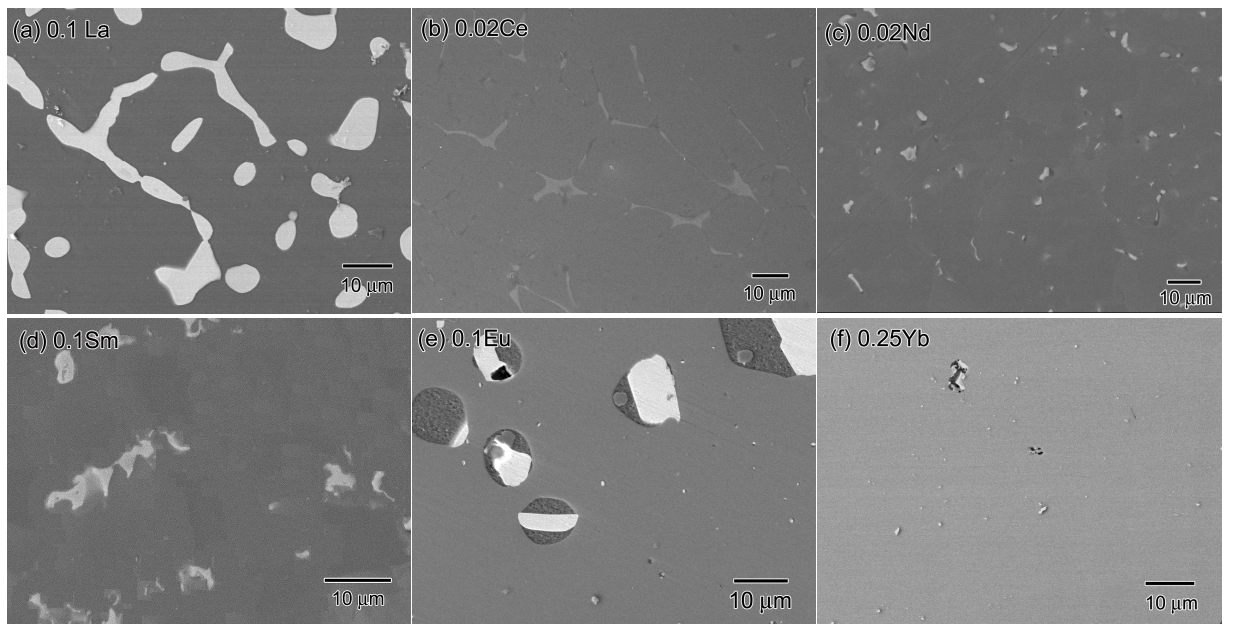
(g) $0.25 \mathrm{Lu}$ $+5$
Fig. 1 Typical microstructures of homogenized $\mathrm{Al}_{3}\left(\mathrm{Sc}_{1-\mathrm{y}} \mathrm{RE} \mathrm{E}_{\mathrm{y}}\right)$ where $\mathrm{RE}$ as (a) La for $\mathrm{y}=0.1$, (b) $\mathrm{Ce}$ for $\mathrm{y}=0.02$, (c) $\mathrm{Nd}$ for $\mathrm{y}=0.02$, (d) Sm for $\mathrm{y}=0.1$, (e) $\mathrm{Eu}$ for $\mathrm{y}=0.1$, (f) $\mathrm{Yb}$ for 0.25 and $(\mathrm{g}) \mathrm{Lu}$ for $\mathrm{y}=0.25$.

porosities, formed during homogenization of the as-cast structure.

Fig. 2 shows typical X-ray diffraction patterns of $\mathrm{Al}_{3}\left(\mathrm{Sc}_{1-\mathrm{y}} \mathrm{RE} \mathrm{y}_{\mathrm{y}}\right)$ with $\mathrm{RE}=\mathrm{Yb}, \mathrm{Sm}$ or La. The X-ray diffraction patterns evolve with increasing ternary RE concentrations, in agreement with the metallographic (Fig. 1) and EDS observations (Table 1). For Yb additions (Fig. 2(a)), the Bragg peaks of the $\mathrm{L}_{2}$ phase are shifted to lower angles with increasing $\mathrm{Yb}$ content. For $\mathrm{y}=0.25$, only the $\mathrm{L} 1_{2}$ phase with $\mathrm{Al}_{3} \mathrm{Sc}$ composition is present, while for $\mathrm{y}=0.50$ and 0.75 , the $\mathrm{Ll}_{2}$ phase with $\mathrm{Al}_{3} \mathrm{Yb}$ composition is formed (see peak 221,310). It is clear that this system shows complete solubility over the composition range studied. In the cases of $\mathrm{Lu}$, we find similarly complete solubility. For Sm additions (Fig. 2(b)), the Bragg peaks of the $\mathrm{L1}_{2}$ phase are slightly shifted to lower angles with 
increasing Sm content. For $\mathrm{y}=0.1$ and 0.25 , only the $\mathrm{L}_{2} \mathrm{Al}_{3} \mathrm{Sc}$ phase is found, while for $\mathrm{y}=0.50$, the $\mathrm{D}_{19} \mathrm{Al}_{3} \mathrm{Sm}$ phase is also visible in the spectra. For all La additions (Fig. 2(c)), the $\mathrm{Al}_{3}$ La phase with $\mathrm{D}_{19}$ structure is found in addition to the $\mathrm{L}_{2}$ phase. Its fraction, as inferred from the peak height, increases with increasing $\mathrm{La}$ concentrations. The XRD patterns for the $\mathrm{Al}_{3}(\mathrm{Sc}, \mathrm{Ce}), \mathrm{Al}_{3}(\mathrm{Sc}, \mathrm{Nd})$ and $\mathrm{Al}_{3}(\mathrm{Sc}, \mathrm{Eu})$

Table 1 Phase composition (measured by EDS quantitative analysis) and lattice parameters (measured by XRD) for alloys are similar to that of the $\mathrm{Al}_{3}(\mathrm{Sc}, \mathrm{La})$ alloy. They confirm that $\mathrm{Al}_{3}\left(\mathrm{Ce}_{1-\mathrm{y}} \mathrm{Sc}_{\mathrm{y}}\right)$ and $\mathrm{Al}_{3}\left(\mathrm{Nd}_{1-\mathrm{y}} \mathrm{Sc}_{\mathrm{y}}\right)$ have the $\mathrm{D}_{19}$ phase, and $\mathrm{Al}_{4}\left(\mathrm{Eu}_{1-\mathrm{y}} \mathrm{Sc}_{\mathrm{y}}\right)$ the $\mathrm{C} 11_{\mathrm{b}}$ structure.

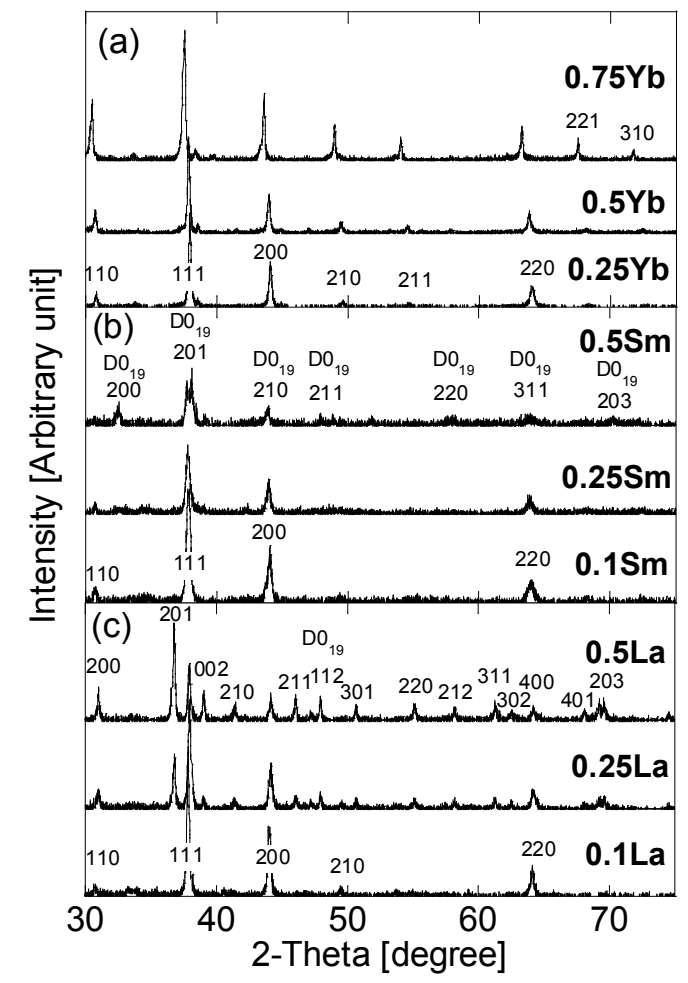

Fig. 2 Typical X-ray diffraction patterns of $\mathrm{Al}_{3}\left(\mathrm{Sc}_{1-\mathrm{y}} \mathrm{RE}_{\mathrm{y}}\right)$ where $\mathrm{RE}$ as (a) $\mathrm{Yb}$ $(\mathrm{y}=0.25,0.5,0.75),(\mathrm{b}) \mathrm{Sm}(\mathrm{y}=0.1,0.25$, $0.5)$ and (c) $\mathrm{La}(\mathrm{y}=0.1,0.25,0.5)$.

\begin{tabular}{|c|c|c|c|c|c|c|c|}
\hline \multirow[t]{2}{*}{ Alloys } & \multicolumn{4}{|c|}{ Structure Chemical composition [at.\%] } & \multirow{2}{*}{$\frac{\text { Volume of } \mathrm{L}_{2}}{\mathrm{f}}$} & \multicolumn{2}{|c|}{ Lattice parameter $[\AA \bar{\AA}]$} \\
\hline & & $\mathrm{Al}$ & Sc & RE & & $\mathrm{a}$ & c \\
\hline $\mathrm{A}_{3} \mathrm{Sc}$ & $\mathrm{L}_{2}$ & $74.8(1)$ & $25.2(1)$ & - & 1.00 & $4.103(1)$ & \\
\hline \multirow[t]{2}{*}{$\mathrm{Al}_{3}\left(\mathrm{Sc}_{0.9 \mathrm{~L}} \mathrm{La}_{0.1}\right)$} & $\mathrm{L}_{2}$ & $75.08(11)$ & $24.85(13)$ & $0.07(4)$ & $0.87(6)$ & $4.103(2)$ & \\
\hline & $\mathrm{DO}_{19}$ & $74.88(34)$ & $1.01(7)$ & $24.11(30)$ & $0.12(3)$ & - & - \\
\hline \multirow[t]{2}{*}{$\mathrm{A}_{3}\left(\mathrm{Sc}_{0.75} \mathrm{La}_{0.25}\right)$} & $\mathrm{L}_{2}$ & $75.02(9)$ & $24.90(15)$ & $0.08(6)$ & 0.70 & $4.103(4)$ & \\
\hline & $\mathrm{DO}_{19}$ & $75.00(33)$ & $0.67(8)$ & $24.33(26)$ & $0.29(9)$ & - & - \\
\hline \multirow{2}{*}{$\mathrm{A}_{3}\left(\mathrm{Sc}_{0.5} \mathrm{La}_{0.5}\right)$} & $\mathrm{L}_{2}$ & $75.07(16)$ & $24.81(16)$ & $0.12(2)$ & 0.49 & $4.103(3)$ & \\
\hline & $\mathrm{DO}_{19}$ & $74.84(44)$ & $0.92(2)$ & $24.24(45)$ & 0.51 & - & - \\
\hline $\mathrm{A}_{3} \mathrm{La}[7]$ & $\mathrm{DO}_{19}$ & - & - & - & - & 6.662 & 4.609 \\
\hline \multirow{2}{*}{$\mathrm{Al}_{3}\left(\mathrm{Sc}_{0.98} \mathrm{Ce}_{0.02}\right)$} & $\mathrm{L}_{2}$ & $75.02(11)$ & $24.96(12)$ & $0.02(2)$ & $0.96(2)$ & $4.103(2)$ & \\
\hline & $\mathrm{DO}_{19}$ & $75.09(22)$ & $4.47(25)$ & $20.44(25)$ & $0.03(7)$ & - & - \\
\hline \multirow[t]{2}{*}{$\mathrm{Al}_{3}\left(\mathrm{Sc}_{0.96} \mathrm{Ce}_{0.04}\right)$} & $\mathrm{L} 1_{2}$ & $75.06(10)$ & $24.87(14)$ & $0.06(6)$ & $0.90(1)$ & $4.103(2)$ & \\
\hline & $\mathrm{DO}_{19}$ & $75.18(64)$ & $7.20(34)$ & $17.62(44)$ & $0.10(9)$ & - & - \\
\hline \multirow[t]{2}{*}{$\mathrm{A}_{3}\left(\mathrm{Sc}_{0.9} \mathrm{Ce}_{0.1}\right)$} & $\mathrm{L}_{2}$ & $75.18(12)$ & $24.74(13)$ & $0.08(5)$ & $0.83(2)$ & $4.103(8)$ & \\
\hline & $\mathrm{DO}_{19}$ & $75.16(29)$ & $7.10(5)$ & $17.74(30)$ & $0.16(7)$ & - & - \\
\hline $\mathrm{A}_{3} \mathrm{Ce}[7]$ & $\mathrm{DO}_{19}$ & - & - & - & - & 6.545 & 4.609 \\
\hline \multirow[t]{2}{*}{$\mathrm{A}_{3}\left(\mathrm{Sc}_{0.98} \mathrm{Nd}_{0.02}\right)$} & $\mathrm{L}_{2}$ & $75.15(14)$ & $24.54(16)$ & $0.31(4)$ & $0.97(9)$ & $4.105(1)$ & \\
\hline & $\mathrm{DO}_{19}$ & $75.10(41)$ & $5.29(6)$ & $19.61(45)$ & $0.02(1)$ & - & - \\
\hline \multirow[t]{2}{*}{$\mathrm{A}_{3}\left(\mathrm{Sc}_{0.96} \mathrm{Nd}_{0.04}\right)$} & $\mathrm{L}_{2}$ & 74.96 (13) & $24.74(13)$ & $0.30(2)$ & $0.95(3)$ & $4.106(2)$ & \\
\hline & $\mathrm{DO}_{19}$ & $75.09(31)$ & $7.16(5)$ & $17.74(35)$ & $0.04(6)$ & - & - \\
\hline \multirow[t]{2}{*}{$\mathrm{A}_{3}\left(\mathrm{Sc}_{0.9} \mathrm{Nd}_{0.1}\right)$} & $\mathrm{L}_{2}$ & $75.01(14)$ & $24.63(20)$ & $0.36(6)$ & $0.85(6)$ & $4.106(2)$ & \\
\hline & $\mathrm{DO}_{19}$ & 75.07 (38) & $9.22(10)$ & $15.71(45)$ & $0.14(4)$ & - & - \\
\hline $\mathrm{A}_{3} \mathrm{Nd}[7]$ & $\mathrm{DO}_{19}$ & - & - & - & - & 6.47 & 4.603 \\
\hline \multirow[t]{2}{*}{$\mathrm{A}_{3}\left(\mathrm{Sc}_{0.9} \mathrm{Sm}_{0.1}\right)$} & $\mathrm{L}_{2}$ & $75.11(11)$ & $22.13(13)$ & $2.76(7)$ & $0.92(7)$ & $4.117(1)$ & \\
\hline & $\mathrm{DO}_{19}$ & 74.94 (49) & $2.23(8)$ & $22.82(55)$ & $0.07(2)$ & - & - \\
\hline \multirow[t]{2}{*}{$\mathrm{A}_{3}\left(\mathrm{Sc}_{0.75} \mathrm{Sm}_{0.25}\right)$} & $\mathrm{L} 1_{2}$ & $74.98(10)$ & $22.15(9)$ & $2.87(3)$ & $0.77(4)$ & $4.124(1)$ & \\
\hline & $\mathrm{DO}_{19}$ & 75.19 (14) & $2.36(5)$ & $22.45(13)$ & $0.22(5)$ & - & - \\
\hline \multirow[t]{2}{*}{$\mathrm{A}_{3}\left(\mathrm{Sc}_{0.5} \mathrm{Sm}_{0.5}\right)$} & $\mathrm{L}_{2}$ & $75.03(11)$ & $21.75(9)$ & $3.22(2)$ & $0.45(8)$ & $4.130(1)$ & \\
\hline & $\mathrm{DO}_{19}$ & $75.08(41)$ & $2.85(9)$ & $22.07(32)$ & $0.54(1)$ & - & - \\
\hline $\mathrm{A}_{3} \mathrm{Sm}[7]$ & $\mathrm{DO}_{19}$ & - & - & - & - & 6.38 & 4.597 \\
\hline \multirow[t]{3}{*}{$\mathrm{A}_{3}\left(\mathrm{Sc}_{0.9} \mathrm{Eu}_{0.1}\right)$} & $\mathrm{L}_{2}$ & $74.79(10)$ & $24.89(12)$ & $0.33(4)$ & $0.90(7)$ & $4.103(1)$ & \\
\hline & $\mathrm{C} 11_{\mathrm{b}}$ & 79.60 (29) & $0.50(8)$ & $19.90(25)$ & $0.05(5)$ & - & - \\
\hline & A & 99.7 & 0.3 & 0 & $0.03(8)$ & - & \\
\hline \multirow{3}{*}{$\mathrm{A}_{3}\left(\mathrm{Sc}_{0.75} \mathrm{Eu}_{0.25}\right)$} & $\mathrm{L}_{2}$ & $74.69(12)$ & $24.89(15)$ & $0.41(10)$ & $0.83(7)$ & $4.103(4)$ & \\
\hline & $\mathrm{C} 11_{\mathrm{b}}$ & $79.59(21)$ & $0.50(7)$ & $19.91(26)$ & $0.13(4)$ & - & - \\
\hline & A & 99.7 & 0.3 & 0 & $0.02(9)$ & - & \\
\hline \multirow[t]{3}{*}{$\mathrm{A}_{3}\left(\mathrm{Sc}_{0.5} \mathrm{Eu}_{0.5}\right)$} & $\mathrm{L}_{2}$ & 74.92 (12) & 24.78 (17) & $0.30(7)$ & $0.48(5)$ & $4.103(9)$ & \\
\hline & $\mathrm{C} 11_{\mathrm{b}}$ & $79.49(21)$ & $0.20(3)$ & $20.31(24)$ & $0.39(7)$ & - & - \\
\hline & $\mathrm{A}^{\circ}$ & 99.7 & 0.3 & 0 & $0.11(8)$ & - & \\
\hline $\mathrm{A}_{4} \mathrm{Eu}[7]$ & $\mathrm{C} 11_{\mathrm{b}}$ & - & - & - & - & 4.398 & 11.17 \\
\hline $\mathrm{A}_{3}\left(\mathrm{Sc}_{0.75} \mathrm{Yb}_{0.25}\right)$ & $\mathrm{L}_{2}$ & $74.79(13)$ & $17.30(15)$ & $7.91(4)$ & $0.98(2)$ & $4.116(3)$ & \\
\hline $\mathrm{A}_{3}\left(\mathrm{Sc}_{0.5} \mathrm{Yb}_{0.5}\right)$ & $\mathrm{L}_{2}$ & 74.70 (19) & $13.80(37)$ & $11.5(22)$ & $0.98(5)$ & $4.131(5)$ & \\
\hline $\mathrm{A}_{3}\left(\mathrm{Sc}_{0.25} \mathrm{Vb}_{0.75}\right)$ & $\mathrm{L}_{2}$ & $74.80(58)$ & $6.30(20)$ & $18.9(72)$ & $0.95(3)$ & $4.169(3)$ & \\
\hline $\mathrm{A}_{3} \mathrm{Yb}[7]$ & $\mathrm{L}_{2}$ & - & - & - & - & 4.204 & \\
\hline $\mathrm{A}_{3}\left(\mathrm{Sc}_{0.75} \mathrm{Lu}_{0.25}\right)$ & $\mathrm{L}_{2}$ & 74.80 (14) & $17.30(13)$ & $7.90(6)$ & $0.99(2)$ & $4.115(1)$ & \\
\hline $\mathrm{A}_{3}\left(\mathrm{Sc}_{0.5} \mathrm{Lu}_{0.5}\right)$ & $\mathrm{L1}_{2}$ & $74.90(36)$ & $13.20(24)$ & $11.91(33)$ & $0.96(1)$ & $4.121(1)$ & \\
\hline $\mathrm{A}_{3}\left(\mathrm{Sc}_{0.25} \mathrm{Lu}_{0.75}\right)$ & $\mathrm{L}_{2}$ & $74.69(22)$ & $4.80(29)$ & $20.50(33)$ & $0.95(9)$ & $4.143(2)$ & \\
\hline $\mathrm{A}_{3} \mathrm{Lu}[7]$ & $\mathrm{L}_{2}$ & - & - & - & - & 4.191 & \\
\hline
\end{tabular}

Solubility Limits for the Rare-Earth Elements. XRD from powder samples and EDS analysis of individual phases from bulk samples can be used to estimate the RE solubility limit in $\mathrm{Al}_{3} \mathrm{Sc}$. The lattice parameters of $\mathrm{Al}_{3} \mathrm{Sc}$ with $\mathrm{La}, \mathrm{Ce}, \mathrm{Nd}, \mathrm{Sm}, \mathrm{Eu}, \mathrm{Yb}$ or $\mathrm{Lu}$ additions are listed in Table 1. The lattice parameters of binary $\mathrm{Al}_{3} \mathrm{La}, \mathrm{Al}_{3} \mathrm{Ce}, \mathrm{Al}_{3} \mathrm{Nd}, \mathrm{Al}_{4} \mathrm{Eu}, \mathrm{Al}_{3} \mathrm{Yb}$ and $\mathrm{Al}_{3} \mathrm{Lu}$ are experimental values reported by Ref. [7]. Furthermore, Table 1 lists the composition of the $\mathrm{Ll}_{2}-\mathrm{Al}_{3} \mathrm{Sc}$ phase measured by EDS as a function of the RE concentration. The lattice constant of the $\mathrm{L}_{2}$ phase increases with increasing $\mathrm{Nd}, \mathrm{Sm}, \mathrm{Yb}$ or $\mathrm{Lu}$ concentrations, but remain near constant with increasing $\mathrm{La}, \mathrm{Ce}$ or $\mathrm{Eu}$ concentrations. For the $\mathrm{Al}_{3}(\mathrm{Sc}, \mathrm{Yb})$ and $\mathrm{Al}_{3}(\mathrm{Sc}, \mathrm{Lu})$ alloys, a decrease in $\mathrm{Sc}$ content in the $\mathrm{Ll}_{2}$ phase is compensated for by an increase $\mathrm{Yb}$ or Lu concentration, while the $\mathrm{Al}$ concentration remains constant. We conclude that $\mathrm{Yb}$ and $\mathrm{Lu}$ replace $\mathrm{Sc}$ in the $\mathrm{L} 1_{2}$ phase and make a complete $\mathrm{L} 1_{2}$ solid-solution. In the case of Sm, the lattice constant of the $\mathrm{L}_{2}$ phase increases with $\mathrm{Sm}$ addition for $\mathrm{y}=0.1$ and 0.25 , but the effect becomes less for $\mathrm{y}=0.5$. The $\mathrm{L}_{2}$ phase exhibits a decrease in $\mathrm{Sc}$ content which is again nearly compensated for by an increase in Sm content, with the Al content remaining constant. As shown in Fig. 1(d) and 2(b), the $\mathrm{D}_{19}$ phase appears already at the lowest Sm concentration $(\mathrm{y}=0.1)$. This suggests that both the $\mathrm{L}_{2}$ and $\mathrm{D}_{19}$ phases have a low solubility limit for ternary elements: 3.22 
at. $\% \mathrm{Sm}$ in the $\mathrm{L}_{2}$ phase $\mathrm{Al}_{3}\left(\mathrm{Sc}_{0.8712} \mathrm{Sm}_{0.1288}\right)$, and 2.85 at.\% Sc in the $\mathrm{D}_{19}$ phase $\mathrm{Al}_{3}\left(\mathrm{Sm}_{0.886} \mathrm{Sc}_{0.114}\right)$ (Table 1). For the lattice parameter changes of $\mathrm{Al}_{3}\left(\mathrm{Sc}_{1-\mathrm{y}} \mathrm{RE} \mathrm{y}_{\mathrm{y}}\right)$ which $\mathrm{RE}=\mathrm{La}, \mathrm{Ce}, \mathrm{Nd}$ and Eu, the lattice constants remain unchanged with increasing RE concentrations in the alloy. Also, RE, Sc and Al contents of the $\mathrm{Ll}_{2}$ phase remain constant. For La additions, the $\mathrm{D} 0_{19}$ phase appears already at the lowest La concentrations ( $\mathrm{y} \leq 0.1$ ) (Fig. 2(c)). These $\mathrm{L1}_{2}$ phases have low solubility limit for RE: about 0.12 at.\% $\mathrm{La}$ in $\mathrm{Al}_{3}\left(\mathrm{Sc}_{0.9952} \mathrm{La}_{0.0048}\right), 0.08$ at.\% $\mathrm{Ce}$ in $\mathrm{Al}_{3}\left(\mathrm{Sc}_{0.9968} \mathrm{Ce}_{0.0032}\right), 0.36$ at.\% $\mathrm{Nd}$ in $\mathrm{Al}_{3}\left(\mathrm{Sc}_{0.9856} \mathrm{Nd}_{0.0144}\right), 0.41$ at.\% $\mathrm{Eu}$ in $\mathrm{Al}_{3}\left(\mathrm{Sc}_{0.9836} \mathrm{Eu}_{0.0164}\right)$. Conversely, the solubility limits of $\mathrm{Sc}$ in the $\mathrm{D} 0_{19}$ phase are about 1.01 at.\% $\mathrm{Sc}$ in $\mathrm{Al}_{3}\left(\mathrm{La}_{0.96} \mathrm{Sc}_{0.04}\right), 7.2$ at.\% $\mathrm{Sc}$ in $\mathrm{Al}_{3}\left(\mathrm{Ce}_{0.712} \mathrm{Sc}_{0.288}\right), 9.22$ at.\% $\mathrm{Sc}$ in $\mathrm{Al}_{3}\left(\mathrm{Nd}_{0.6321} \mathrm{Sc}_{0.3688}\right)$ and 0.5 at.\% $\mathrm{Sc}$ in $\mathrm{Al}_{3}\left(\mathrm{Eu}_{0.98} \mathrm{Sc}_{0.02}\right)$. Table 1 summarizes the lattice parameters and the EDS quantitative analyses of binary $\mathrm{Al}_{3} \mathrm{Sc}$ and the ternary alloys. From the experimentally-measured phase composition, the volume fraction of the $\mathrm{Ll}_{2}$ phase was calculated by mass conservation. Reasonable agreement is found with values found independently from image analysis of optical micrographs.

In summary, rare-earth elements $\mathrm{La}, \mathrm{Ce}, \mathrm{Nd}, \mathrm{Sm}, \mathrm{Eu}, \mathrm{Yb}$ or $\mathrm{Lu}$ can be incorporated substitutionally in the Sc sublattice of $\mathrm{Al}_{3} \mathrm{Sc}$ (Figs. 1, 2 and Table 1). Binary trialuminides of the rare-earth elements $\mathrm{Yb}$ and $\mathrm{Lu}$ can crystallize in the $\mathrm{L}_{2}$ structure, while trialuminides of $\mathrm{La}, \mathrm{Ce}, \mathrm{Nd}$ and $\mathrm{Sm}$ have long period $\mathrm{D}_{19}$ structures, which are related closely to the cubic $\mathrm{L1}_{2}$ structure. It has been reported that Er, $\mathrm{Tm}, \mathrm{Yb}$ and $\mathrm{Lu}$ trialuminides crystallize in the $\mathrm{L}_{2}$ structure which can form a complete $\mathrm{L}_{2}$ solid-solution with $\mathrm{Al}_{3} \mathrm{Sc}$ [8]. On the other hand, the solubility limit in the $\mathrm{L}_{2}$ phase of $\mathrm{Gd}, \mathrm{Tb}$, Dy and $\mathrm{Ho}$ has been found to be: $\mathrm{Al}_{3}\left(\mathrm{Sc}_{0.85} \mathrm{Gd}_{0.15}\right), \mathrm{Al}_{3}\left(\mathrm{Sc}_{0.57} \mathrm{~Tb}_{0.43}\right), \mathrm{Al}_{3}\left(\mathrm{Sc}_{0.40} \mathrm{Dy}_{0.60}\right), \mathrm{Al}_{3}\left(\mathrm{Sc}_{0.28} \mathrm{Ho}_{0.72}\right)$ [9]. These previous results and the present ones indicate that the solid solubility in the $\mathrm{L}_{2}$ phase varies systematically with the location of the rare-earth element in the periodic table. The late RE (Dy, $\mathrm{Ho}, \mathrm{Er}, \mathrm{Tm}, \mathrm{Yb}$ and $\mathrm{Lu}$ ) have a larger solid solubility in $\mathrm{Al}_{3} \mathrm{Sc}$ than the early $\mathrm{RE}$ ( $\mathrm{La}, \mathrm{Ce}, \mathrm{Nd}, \mathrm{Sm}, \mathrm{Eu}$ or $\mathrm{Gd}$ ). The late $\mathrm{RE}$ are thus good alloying elements candidates to replace substitutionally $\mathrm{Sc}$ in $\mathrm{L}_{2}$ ternary $\mathrm{Al}_{3}(\mathrm{Sc}, \mathrm{RE})$ trialuminides.

Lattice Parameter as a Function of the Rare-Earth Elements. Figure 3 show the relationship between the concentration of various $\mathrm{Re}$ in the $\mathrm{L1}_{2}$ phase (as measured by EDS) and the lattice parameter of the $\mathrm{L}_{2}$ phase (as measured by XRD), together with previous data for $\mathrm{RE}=\mathrm{Gd}, \mathrm{Tb}, \mathrm{Dy}$, Ho, $\operatorname{Er}[9]$ and $\mathrm{Tm}$ [10]. As shown in these figures, there is a linear relationship between lattice parameter and concentration.

For the low-solubility early $\mathrm{RE}(\mathrm{La}, \mathrm{Ce} \mathrm{Eu}$ and $\mathrm{Nd})$, it is difficult to quantify the effect, but the concentration dependence of the $\mathrm{L}_{2}$ lattice parameter seems to be low, and similarto that for $\mathrm{Sm}$ (Fig. 3(b)). As shown in Fig. 3(b), the $\mathrm{L1}_{2}$ lattice parameter for $\mathrm{Yb}$ or $\mathrm{Lu}$ addition increases linearly with an increasing ternary concentration, similar to previous data for the late RE (Gd, Tb, Dy, Ho, Er [9] and Tm [10]).
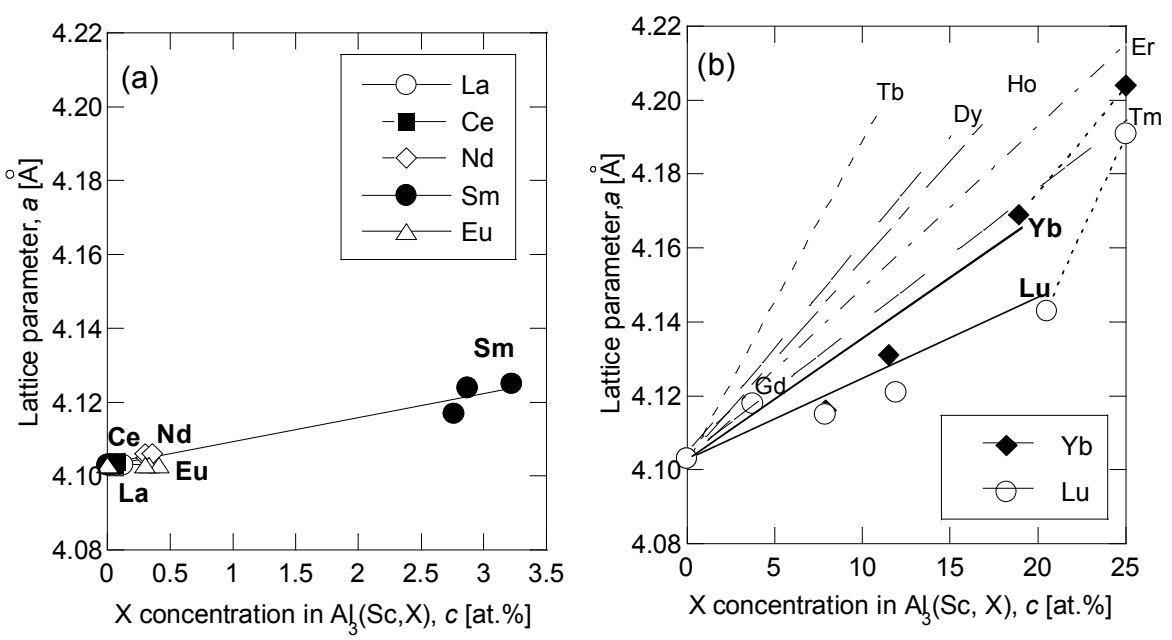

Fig. 3 Lattice parameter of the $\mathrm{Ll}_{2}$ phase in $\mathrm{Al}_{3}(\mathrm{Sc}, \mathrm{RE})$ as a function of (a) $\mathrm{RE}=\mathrm{La}, \mathrm{Ce}, \mathrm{Nd}, \mathrm{Sm}, \mathrm{Eu}$ and (b) $\mathrm{RE}=\mathrm{Yb}, \mathrm{Lu}, \mathrm{Gd}, \mathrm{Tb}, \mathrm{Dy}, \mathrm{Ho}, \mathrm{Er}, \mathrm{Tm}$.

From the linear relationship between concentration and lattice parameter of the solid- solution $\mathrm{L}_{2}$ phase (Fig. 3), a best-fit slope, $d a / d c$, is determined. Fig. 4 shows that this slope, i.e. the composition dependence of $\mathrm{L}_{2}$ lattice parameter together wtih the previously-determined slopes for transition-metals additions [2], correlates reasonably well with the relative atomic radius mismatch, $d R / R=\left(R_{X}-R_{S c}\right) / R_{X}$, where $R$ is the metallic hard-sphere radius from Ref. [11] (no significant 
difference was found in the correlation when ionic Pauling's radii were used). A similar correlation was found by Yamamoto et al. [12] for the $\mathrm{L}_{2}$ quaternary phase $\left\{(\mathrm{AlMn})_{3} \mathrm{Ti}\right\}_{(1-\mathrm{n})} \mathrm{X}_{\mathrm{n}}$, where $\mathrm{X}$ is $=\mathrm{Zr}$, $\mathrm{V}, \mathrm{Ag}$ or, Ga. This correlation can be understood in terms of the size mismatch associated with the replacement of solvent atoms with solute atoms causing a distortion of the lattice. The resulting strain field may allow solute atoms to interact strongly with dislocations, thus affecting the strength of the solid solution, as discussed in the following section.

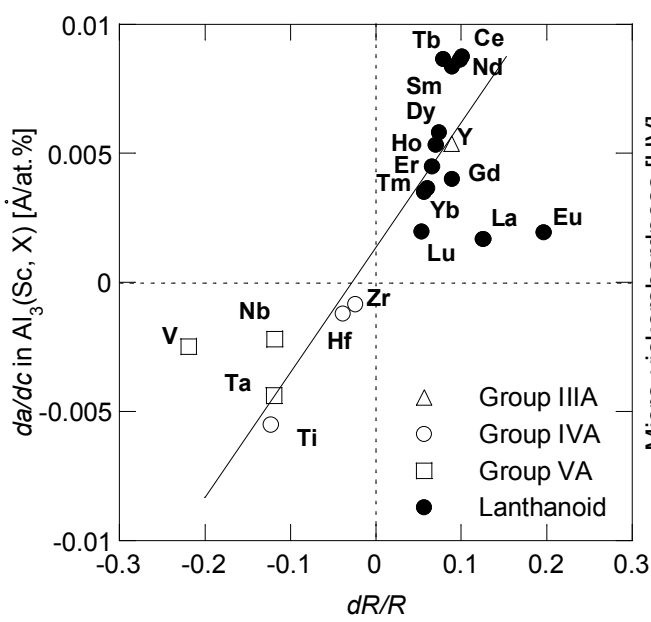

Fig. 4 Relationship between $d R / R$ and da/dc in $\mathrm{Al}_{3}(\mathrm{Sc}, \mathrm{X})$ with $\mathrm{X}=$ transition metals (TM) and rare-earth (RE).
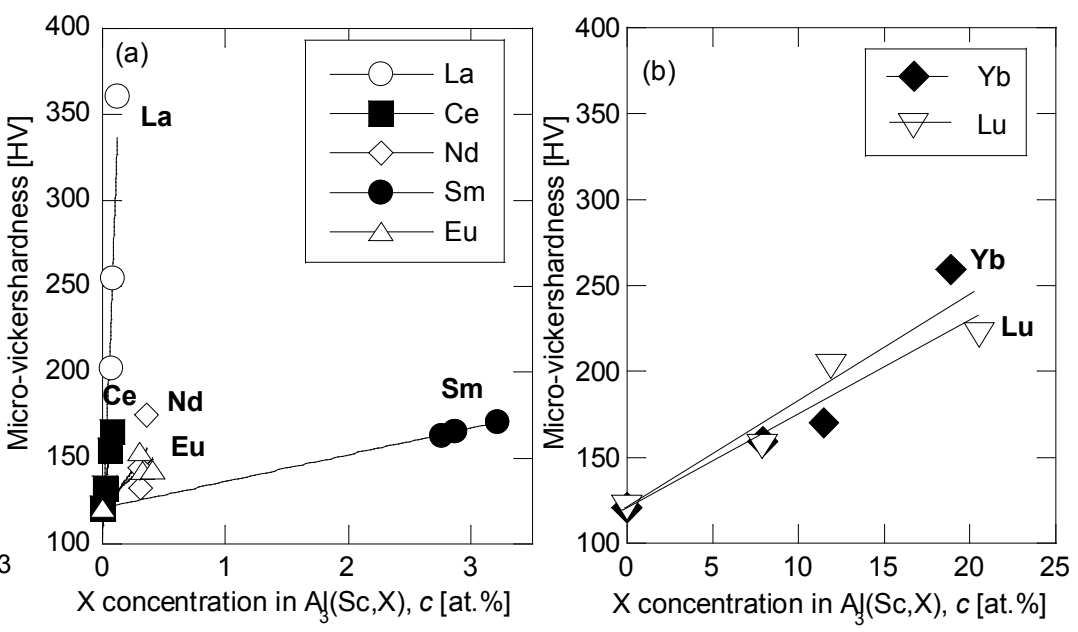

Fig. 5 Vickers microhardness of $\mathrm{L}_{2}$ phase in $\mathrm{Al}_{3}(\mathrm{Sc}, \mathrm{RE})$ as afunction of (a) $\mathrm{RE}=\mathrm{La}, \mathrm{Ce}, \mathrm{Nd}, \mathrm{Sm}, \mathrm{Eu}$ and (b) $\mathrm{RE}=\mathrm{Yb}$, Lu..

Micro-Hardness as a Function of the Rare-Earth Elements. The Vickers micro-hardness of binary $\mathrm{Al}_{3} \mathrm{Sc}$ was found to be $121 \mathrm{HV}$ [2]. This value is very close to the value $(111 \mathrm{HV})$ reported by Nic et al. [13]. but lower than the value $(140 \mathrm{HV})$ reported by Schneibel et al. [14] for drop-cast $\mathrm{Al}_{3} \mathrm{Sc}$. Fig. 5 shows the micro-hardness of alloyed $\mathrm{Al}_{3} \mathrm{Sc}$ as a function of the RE concentration in the ternary $\mathrm{L}_{2}$ phase (as obtained by EDS). In Fig. 5(a), the hardness increase for the early RE is modest for Ce, Nd, $\mathrm{Eu}$ or $\mathrm{Sm}$, as expected from their low solubility in the $\mathrm{L}_{2}$ phase. A much larger hardening effect is associated with La, despite its similarly low solubility: the hardest $\mathrm{Ll}_{2}$ composition $\mathrm{Al}_{3}\left(\mathrm{Sc}_{0.9952} \mathrm{La}_{0.0048}\right)$ is more than three times as hard as binary $\mathrm{Al}_{3} \mathrm{Sc}$. However, the presence of finely-dispersed $\mathrm{D}_{19}-\mathrm{Al}_{3} \mathrm{La}$ within the $\mathrm{L}_{2}$ phase may be the reason for this anomalous hardness increase. Finally, as shown in Fig. 5(b), the late RE Yb and Lu, with complete solubility in Al3Sc, show a linear hardness increase with $\mathrm{RE}$ content, with hardness doubling from $\mathrm{Al}_{3} \mathrm{Sc}$ to $\mathrm{Al}_{3}\left(\mathrm{Sc}_{0.25} \mathrm{RE}_{0.75}\right)$.

In an earlier paper [3], we investigated the compressive creep behavior for $\mathrm{Al}_{3}\left(\mathrm{Sc}_{0.74} \mathrm{TM}_{0.26}\right)$, where TM is one of the transition-metal of Ti, Y, Zr or, Hf. At $873 \mathrm{~K}$, a decrease in creep rates of one order of magnitude was found for $\mathrm{Zr}$ and $\mathrm{Hf}$, and two orders of magnitude for $\mathrm{Ti}$ and $\mathrm{Y}$. These trends were in reasonably good agreement with the room temperature hardness of the alloys. The exact mechanism responsible for solid-solution strengthening at ambiant and elevated temperatures must await precise observations of dislocations in indented or compressively-deformed specimens, as many factors may be operating, e.g., interaction of solute atoms with vacancies and dislocation jogs, segregation on stacking faults and increase of the Peierls stress. Based on the present hardness measurements, the addition of $\mathrm{Sm}, \mathrm{Yb}$ or $\mathrm{Lu}$ to $\mathrm{Al}_{3} \mathrm{Sc}$ can be expected to improve the creep resistance of the ternary intermetallic.

\section{Summary}

The microstructure of the ternary trialuminide $\mathrm{Al}_{3}\left(\mathrm{Sc}_{1-\mathrm{y}} \mathrm{RE}_{\mathrm{y}}\right)$ - where $\mathrm{RE}$ is one of the rare-earth elements $\mathrm{La}, \mathrm{Ce}, \mathrm{Nd}, \mathrm{Sm}, \mathrm{Eu}, \mathrm{Yb}, \mathrm{Lu}$ - was investigated as a function of concentration in the range $0<$ $\mathrm{y} \leq 0.75$. Cast alloys with $\mathrm{La}, \mathrm{Ce}, \mathrm{Nd}, \mathrm{Sm}$ or Eu additions exhibit a microstructure consisting of a $\mathrm{L}_{2}$ 
solid-solution phase containing a dendritic second phase with the $\mathrm{D}_{19}(\mathrm{La}, \mathrm{Ce}, \mathrm{Nd}, \mathrm{Sm})$ or $\mathrm{C} 11_{\mathrm{b}}(\mathrm{Eu})$ structure. Alloys with $\mathrm{Yb}$ or Lu additions show a single majority $\mathrm{L}_{2}$ phase. After long-time annealing at $\mathrm{xx}{ }^{\circ} \mathrm{C}$, the solubility limits in the $\mathrm{L1}_{2}-\mathrm{Al}_{3}\left(\mathrm{Sc}_{1-\mathrm{y}} \mathrm{RE}_{\mathrm{y}}\right)$ phase was about 0.12 at. $\%$ ( $\left.\mathrm{y}=0.0048\right)$ for $\mathrm{La}$, 0.08 at. $\%(y=0.0032)$ for $\mathrm{Ce}, 0.36$ at. $\%(y=0.0144)$ for $\mathrm{Nd}, 3.22$ at. $\%(\mathrm{y}=0.1288)$ for $\mathrm{Sm}$ and 0.41 at. $\%$ $(\mathrm{y}=0.0164)$ for $\mathrm{Eu}$. Conversely, $\mathrm{Yb}$ and Lu exhibited a complete solid solubility in the $\mathrm{L}_{2}$ phase. The lattice parameter of the $\mathrm{Ll}_{2}-\mathrm{Al}_{3}\left(\mathrm{Sc}_{1-\mathrm{y}} \mathrm{RE}_{\mathrm{y}}\right)$ increases linearly with increasing concentration of $\mathrm{Nd}, \mathrm{Sm}$, $\mathrm{Yb}$ or $\mathrm{Lu}$ and remains constant with additions of $\mathrm{La}, \mathrm{Ce}$ or $\mathrm{Eu}$, due to their very small solubility. The concentration-dependence of the lattice parameter correlates well with the Sc/RE atomic size mismatch. The Vickers micro-hardness of $\mathrm{Ll}_{2}-\mathrm{Al}_{3}\left(\mathrm{Sc}_{1-\mathrm{y}} \mathrm{RE} \mathrm{y}_{\mathrm{y}}\right)$ increases linearly with increasing ternary concentration.

Acknowledgments - Partial support from grant DE-FG02-98ER45721 from the US Department of Energy is acknowledged.

\section{References}

[1] J.H. Schneibel and P.M. Hazzledine: J. Mater. Res. Vol. 7 (1992), p. 868.

[2] Y. Harada and D.C. Dunand: Mater. Sci. Eng. Vol. A329-331 (2002), p. 686.

[3] Y. Harada and D.C. Dunand: Acta Mater. Vol. 48 (2000), p. 3477.

[4] C.B. Fuller, D.N. Seidman and D.C. Dunand: Scr. Mater. Vol. 40 (1999), p. 691.

[5] L.S. Toropova, D.G. Eskin, M.L. Kharakterova and T.V. Dobatkina: Advanced Aluminum Alloys Containing Scandium (Gordon and Breach Science Publisher, Amsterdam 1998).

[6] R.R. Sawtell and J.W. Morris: Dispersion Strengthened Aluminum Alloys (TMS, Phoenix, AZ 1988), p. 409.

[7] The Powder Diffraction File and Related Products (ICDD, Newtown Square, PA 2005).

[8] P. Villars and L.D. Calvert: Pearson's Handbook of Crystallographic Data for Intermetallic Phases (ASM, Metal Park, OH 1985).

[9] O.I. Zalutska, V.G. kontsevii, N.I. Karamishev, V.R. Ryalov and I.I. Zalutskii: Dopovidi Akad. Nauk Ukr. RSR Vol. A (1970), p.751.

[10] O.I. Zalutska, E.E. Cherkashin and I.I. Zalutsky: Strukt. Faz, Fazovye Prevrashch. Diagr. Sostoyaniya Met. Sist. (Publ. Nauka, Moscow 1974).

[11] E.T. Teatum, K.A. Gshneidner and J.T. Waber: Report of Los Alamos Scientific Laboratory of the University of California, LA-2345 (Department of Commerce, Washington, DC 1968).

[12] Y. Yamamoto, K. Hashimoto, T. Kimura, H. Moriya, N. Nobuki and N. kohno: J. Jpn. Inst. Metals Vol. 62 (1998), p. 844.

[13] J.P. Nic, S. Zhang and D.E. Mikkola: High Temperature Ordered Intermetallic Alloys IV (MRS, Pittsburgh, PA 1990).

[14] J.H. Schneibel and E.P. George: Scr. Metall. Mater. Vol. 24 (1990), p. 1069. 